\title{
Feasibility of using sea surface temperature imagery to mitigate cheloniid sea turtle-fishery interactions off the coast of northeastern USA
}

\author{
Joanne Braun-McNeill ${ }^{1, *}$, Christopher R. Sasso ${ }^{2}$, Sheryan P. Epperly ${ }^{2}$, Carlos Rivero ${ }^{2}$ \\ ${ }^{1}$ National Marine Fisheries Service, Southeast Fisheries Science Center, 101 Pivers Island Rd., Beaufort, \\ North Carolina 28516, USA \\ ${ }^{2}$ National Marine Fisheries Service, Southeast Fisheries Science Center, 75 Virginia Beach Dr., Miami, Florida 33149, USA
}

\begin{abstract}
As sea turtles migrate along the Atlantic coast of the USA, their incidental capture in fisheries is a significant source of mortality. Because distribution of marine cheloniid turtles appears to be related, in part, to sea surface temperature (SST), the ability to predict water temperature over the continental shelf could be useful in minimizing turtle-fishery interactions. We analyzed $10 \mathrm{yr}$ of advanced very high resolution radiometer (AVHRR) SST imagery to estimate the proportion of 18 spatial zones, nearshore and offshore of Hatteras, North Carolina, USA $\left(35^{\circ} \mathrm{N}\right)$, to north of Cape Sable, Nova Scotia $\left(44^{\circ} \mathrm{N}\right)$, at temperatures $>10$ to $15^{\circ} \mathrm{C}$, by week. Detailed examples for $11^{\circ} \mathrm{C}$, the temperature employed by some management actions in the study area, and for $14^{\circ} \mathrm{C}$, the lowest temperature at which turtles were sighted by some studies in the area, demonstrate a predictable pattern of rapid warming in March and April, followed by rapid cooling in October and November, with nearshore waters warming more rapidly than those offshore. Of those loggerhead turtles Caretta caretta that stranded, were sighted, or were incidentally captured between Cape Hatteras, North Carolina, and Cape Cod, Massachusetts, those at lower latitudes occurred when $25 \%$ or more of the area reached a water temperature of $11^{\circ} \mathrm{C}$, while those in the northern zones did not occur until $50 \%$ or more of the area had reached a water temperature of $14^{\circ} \mathrm{C}$. This analysis provides a means of predicting marine cheloniid turtle presence, which can be helpful in regulating fisheries that seasonally interact with turtles.
\end{abstract}

KEY WORDS: Cheloniid $\cdot$ Management $\cdot$ Sea turtles $\cdot$ Sea surface temperature $\cdot$ Sea turtle-fishery interaction

\section{INTRODUCTION}

Sea turtles are poikilotherms and, with the exception of the leatherback Dermochelys coriacea (James \& Mrosovsky 2004), have distributions that are limited geographically and temporally by water temperature. Although leatherback turtles can maintain a body core temperature at an average of $8^{\circ} \mathrm{C}$ above ambient temperatures (James \& Mrosovsky 2004) and have been documented in the Atlantic in waters off eastern Canada (Bleakney 1965, Lazell 1980, Goff \& Lien 1988), where the water was as cold as $0^{\circ} \mathrm{C}$ (Goff \& Lien 1988), temperatures need to remain above certain levels in order for marine cheloniid turtles (such as loggerhead Caretta caretta, green Chelonia mydas and Kemp's ridley Lepidochelys kempii sea turtles) to maintain physiological functions. Temperatures that are too high or too low will negatively impact the feeding behavior of these sea turtles, locomotor movements, and stress hormone levels (for a review, see Milton \& Lutz 2003).

For example, Birse \& Davenport (1987) found that temperature had a great effect on the rate of food passage through the digestive system of small $(<2500 \mathrm{~g})$ loggerheads, even though the turtles were allowed to acclimate at the test temperature (from a holding tem- 
perature of $25^{\circ} \mathrm{C}$ ) for 4 to $5 \mathrm{~d}$ before testing. Likewise, captive, immature green ( 8 yr old) and Kemp's ridley (3 yr old) sea turtles displayed semi-dormant behavior and stopped feeding when water temperatures decreased to $<15^{\circ} \mathrm{C}$ (Moon et al. 1997). Schwartz (1978) reported that immature loggerhead, green, and Kemp's ridley sea turtles held in shallow, outdoor ponds in North Carolina quit feeding and began floating when temperatures reached 9 to $10^{\circ} \mathrm{C}$, with a lethal temperature for all 3 species between 5 and $6.5^{\circ} \mathrm{C}$. Davenport et al. (1997) discovered that swimming coordination in 1 mo old green turtles was compromised at $15^{\circ} \mathrm{C}$. In other studies, captive sub-adult loggerhead sea turtles exposed to water temperatures that rapidly decreased at a rate of $2.5^{\circ} \mathrm{C} \mathrm{d}^{-1}$ (from 30 to $10^{\circ} \mathrm{C}$ ) had a failure of important metabolic processes between 10 and $15^{\circ} \mathrm{C}$ (Lutz \& Dunbar-Cooper 1984, Lutz et al. 1989). Even when temperatures were slowly reduced by 5 to $6^{\circ} \mathrm{C}$ every $2 \mathrm{wk}$, captive turtles continued showing signs of stress (Moon et al. 1997). Clearly, temperatures below a certain tolerance level hinder the turtles' ability to function.

In addition to affecting their physiology, water temperatures can influence sea turtle migratory behavior and movement patterns. During spring, as water temperatures begin to increase, cheloniid marine turtles migrate north along the United States Atlantic coast and into inshore waters; in autumn, as water temperatures decrease, this migratory pattern is reversed (Shoop \& Kenney 1992, Witzell \& Azarovitz 1996, Musick \& Limpus 1997, Morreale \& Standora 1998, Braun-McNeill \& Epperly 2002, Morreale \& Standora 2005). When conducting aerial surveys off North Carolina and Virginia, Coles \& Musick (2000) reported that only one of the 16 turtles sighted was in waters colder than $14^{\circ} \mathrm{C}\left(13.3^{\circ} \mathrm{C}\right)$, while Witzell \& Azarovitz (1996) reported no sightings along the entire United States Atlantic coast in waters colder than $14^{\circ} \mathrm{C}$. Similarly, water temperatures experienced by satellitetagged adult loggerhead turtles wintering along the edge of the Gulf Stream of the southeast USA ranged from 14 to $26^{\circ} \mathrm{C}$, warmer than nearby inshore waters where temperatures regularly fell below 8 to $10^{\circ} \mathrm{C}$ (Hawkes et al. 2007). In all these studies, colder waters were available, but no sea turtles were observed in the coldest waters.

Although the previously mentioned studies provide some documentation that marine cheloniid turtles are intolerant of waters $<15^{\circ} \mathrm{C}$, other observations of wild turtles indicate that, in certain circumstances, some can acclimate to cooler temperatures. Carr et al. (1980) uncovered juvenile and adult loggerheads buried in the mud off Cape Canaveral, Florida, when waters averaged $11^{\circ} \mathrm{C}$, but found them swimming off the bottom by mid-March when waters had warmed to almost $20^{\circ} \mathrm{C}$. Nine rehabilitated loggerhead turtles tracked in the Mediterranean Sea remained active to some degree and continued to feed throughout the winter despite experiencing temperatures $<15^{\circ} \mathrm{C}$ (minimum of $11.8^{\circ} \mathrm{C}$ ) (Hochscheid et al. 2007).

Sea turtles also may be able to adapt to cooler temperatures if the rate of change is slow enough (Milton \& Lutz 2003). Epperly et al. (1995) sighted cheloniid turtles off North Carolina during aerial surveys in waters as cold as $8^{\circ} \mathrm{C}$ and also reported capturing active turtles with bottom trawls in waters as cold as $10^{\circ} \mathrm{C}$. Similarly, turtles were captured in pound nets in North Carolina, even as water temperatures dropped to $<10^{\circ} \mathrm{C}$ (Epperly et al. 2007). Likewise, water temperature data recorded for 12 of the 14 sea turtles observed captured in the monkfish fishery off North Carolina and Virginia ranged from 8.6 to $12.7^{\circ} \mathrm{C}$ and averaged $12.1^{\circ} \mathrm{C}$ (NMFS [National Marine Fisheries Service] 2001a). During aerial surveys, Shoop \& Kenney (1992) reported 8 sightings of loggerhead turtles in waters $\leq 10^{\circ} \mathrm{C}$ off the northeast coast of the USA, and a loggerhead turtle was reported actively swimming on the south coast of Newfoundland when water temperatures were $8^{\circ} \mathrm{C}$ (Ledwell 2007). Finally, telemetric studies of sea turtles also have documented the presence of turtles in waters $<15^{\circ} \mathrm{C}$. For example, 3 of 6 wild loggerheads were tracked in waters between 6 and $9^{\circ} \mathrm{C}$ (Keinath 1993), and Kemp's ridleys that were tracked in the waters surrounding Long Island, New York, displayed active, directed movements when ambient temperatures were $<15^{\circ} \mathrm{C}$ (Standora et al. 1989). Although most cheloniid marine turtles are found in water temperatures $>20^{\circ} \mathrm{C}$, managers need to be mindful of the fact that certain species (e.g. loggerheads) and/or larger individuals (sub-adults and adults) can tolerate lower water temperatures (Spotila et al. 1997) when evaluating the risk for sea turtles interacting with a particular fishery.

As they embark upon their spring and autumn migrations over the continental shelf off the northeast USA, sea turtles are vulnerable to incidental capture by fisheries, including trawls (Epperly 2003, Murray 2006), gill nets (NMFS 2001a), scallop dredges (Murray 2007), and pots and traps (Allen 2000). Because the northern distribution of cheloniid marine turtles appears to be seasonally related to water temperature, at least northward to Cape Cod (Shoop \& Kenney 1992, Witzell \& Azarovitz 1996), a means of predicting SST and, thus, sea turtle presence in an area could provide a mechanism for mitigating sea turtle-fishery interactions. The NMFS implemented the use of a minimum temperature to mitigate sea turtle-fishery interactions in ocean waters off North Carolina and Virginia (Epperly et al. 1995, 1996, NMFS 2001a). After determining that the likelihood of sea turtle captures is 
negligible when surface water temperatures fall below $11^{\circ} \mathrm{C}$ (Epperly et al. 1995), the NMFS eliminated the requirement for turtle excluder devices (TEDs) between Oregon Inlet, North Carolina, and Cape Charles, Virginia, from January 15 to March 15 in the winter trawl fishery for summer flounder Paralichtys dentatus (NMFS 1996). They also established a seasonal closure of the large-mesh gill net fishery for goosefish (monkfish) Lophius spp., based on a minimum temperature of $11^{\circ} \mathrm{C}$ to prevent interactions when sea turtles were present (NMFS 2002). Our objective is to provide a method of predicting potential sea turtle presence along the northeast coast of the USA, which, in turn, can be useful in the management of fisheries that interact with sea turtles by assessing the likelihood of turtle presence in a management area at different times of the year.

We analyzed SST imagery and calculated the areal proportion of surface waters above temperatures ranging from 10 to $15^{\circ} \mathrm{C}$ in ocean waters from just south of Cape Hatteras, North Carolina, to Cape Sable, Nova Scotia. This range in temperatures was chosen based on the historical precedent of using $11^{\circ} \mathrm{C}$ as a potential minimal temperature employed in the seasonal regulation of sea turtle-fishery interactions (Epperly et al. $1995,1996)$, and research that identified $14^{\circ} \mathrm{C}$ as another possible minimal temperature for sea turtles (Coles \& Musick 2000, Witzell \& Azarovitz 1996).
1993 to 2002, resulting in 690 images. The pixel size of images from 1993 to 1994 was $4.410 \mathrm{~km}$ (rows $=512$, columns $=512$ ), while the pixel size of images from 1995 to 2002 was $1.4699 \mathrm{~km}$ (rows $=1401$, columns = 1302). Images were registered using the CoastWatch GeoCorrector Extension for ArcView GIS 3.3 (ESRI 2000). The original data were in the Mercator projection, and an $x y$ shift was applied to line up the image with the vector shoreline.

We defined 18 zones whose northern/southern boundaries were spaced at 30' intervals from just south of Cape Hatteras, North Carolina $\left(35^{\circ} \mathrm{N}\right)$, to north of Cape Sable, Nova Scotia $\left(44^{\circ} \mathrm{N}\right)$ (Fig. 1). We also defined 2 strata in each of these zones: nearshore, the coastline (from the COLREGS demarcation line) to $20 \mathrm{~m}$ depth; and offshore, shelf waters from 20 to $200 \mathrm{~m}$ in depth. We imported the selected images into ArcView GIS 3.3 with Spatial Analyst as ArcView grids, with a cell resolution of $1.46 \times 1.46 \mathrm{~km}$ (Environmental Systems Research Institute). We then reclassified each raster to $1^{\circ} \mathrm{C}$ temperature bins and tabulated the area within each zone that fell within a specific temperature bin from 0 to $35^{\circ} \mathrm{C}$.

From these temperature distributions, we calculated the proportion of the zone at or above a particular temperature, from 10 to $15^{\circ} \mathrm{C}$, for each week of the year. Second-order polynomial curves were then fit to $10 \mathrm{yr}$ of weekly data for each of the 18 zones, 2 strata, and 6

\section{MATERIALS AND METHODS}

SST imagery was provided by the NOAA Satellite and Information Service, Comprehensive Large Array-Data Stewardship System (National Environmental Satellite, Data and Information Service, August 28, 2003, www.class.noaa.gov/) from the CoastWatch Northeast Regional Node. NOAA CoastWatch SST images are acquired by the advanced very high resolution radiometer (AVHRR) sensor on board NOAA polar operational environmental satellites (POES), and are produced 4 times daily for the coastal waters of the United States. All images were initially viewed using Windows Image Manager (WIM), a software package that allows display and analysis of images (Windows Image Manager, June 12, 2008, www.wimsoft. com/). Only images free of cloud cover and other obstructions were selected at approximately 7 to 14 d intervals beginning January 1 and ending December 31 for the years from

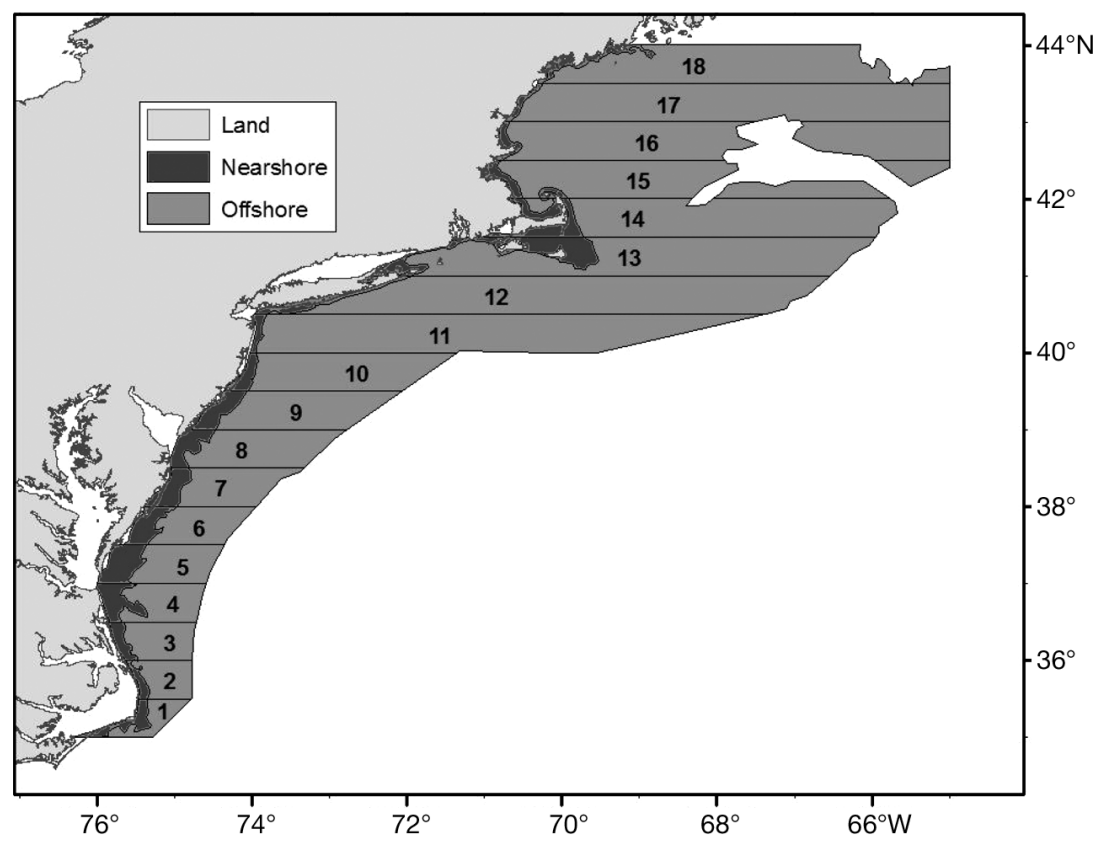

Fig. 1. Zones and depth stratum polygons from which sea surface temperature data were extracted from Cape Hatteras, North Carolina, to Cape Sable, Nova Scotia, from 1993 to 2002. The nearshore strata represent the coastline (from the COLREGS demarcation line) to the $20 \mathrm{~m}$ depth contour, and offshore strata represent shelf waters from 20 to $200 \mathrm{~m}$ in depth 
temperatures $\left(10\right.$ to $\left.15^{\circ} \mathrm{C}\right)$ using the GLM procedure in SAS Version 9.1.2 to predict by week what proportion of each stratum in each zone was above the given temperature. Because the lowest temperatures were reached in mid-February, our thermal year began February 19 and all analyses were adjusted accordingly. We provide detailed results for both 11 and $14^{\circ} \mathrm{C}$, while results for $10,12,13$, and $15^{\circ} \mathrm{C}$ are provided in $\mathrm{Ap}$ pendix 1 (available as Supplementary Material at: www.int-res.com/journals/suppl/n005p257_app.pdf). Finally, we demonstrate how water temperatures changed along the Atlantic coast at different times of the year and when different proportions of a zone reached a given temperature.

\section{RESULTS}

The proportion of a zone at or above 11 and $14^{\circ} \mathrm{C}$ varied through time, but yielded a predictable pattern of rapid warming in March and April, followed by rapid cooling in October and November (Figs. 2 \& 3). Generally, shallow nearshore waters warmed more rapidly than deeper offshore waters in the spring and cooled more rapidly than offshore waters in the autumn. Models for both temperatures and all zones were significant $(p<0.001$; Table 1$)$. The lower Rsquared values for Zone 1 are likely due to shifts in the Gulf Stream and northeasterly winds, which can rapidly alter SSTs in this area (Epperly et al. 1995).

To demonstrate how water temperatures changed along the Atlantic coast at different times of the year and when different proportions of a zone reached a given temperature, we provide detailed examples arbitrarily using the dates when 25 and $50 \%$ of the zones reached 11 and $14^{\circ} \mathrm{C}$ (Fig. 4, temperature lines only). Of these examples, the most conservative approach $\left(25 \%\right.$ of a zone at or above $11^{\circ} \mathrm{C}$ ) indicates a need for sea turtle conservation regulations in the nearshore and offshore waters of the southernmost zone all year, with the need for regulations in the most northern zone as early as April 16 in nearshore waters and April 23 in offshore waters. Using the least conservative approach $\left(50 \%\right.$ at or above $\left.14^{\circ} \mathrm{C}\right)$, sea turtle conservation regulations would not be needed in the southernmost zone until March 19 in offshore waters and April 2 in nearshore waters, with the need for regulations in the most northern zone as late as June 11 in nearshore waters and July 23 in offshore waters.

\section{DISCUSSION}

Despite the documented occurrence of the incidental capture of sea turtles in many fishing gears, there are still many fisheries in the USA without regulations to mitigate these effects (dredges [Murray 2007, Haas et al. 2008]; gill nets [Epperly et al. 1995, NCMFC 2006]; hook and line [Epperly et al. 1995, NMFS 2005]; pots and traps [Allen 2000]; pound nets [Morreale \& Standora 2005, Epperly et al. 2007]; and trawls [Murray 2006, 2007]; see also NMFS SEFSC 2001, their Appendix 2), and several fisheries mentioned in the 'Introduction' with regulations covering only a part of the geographic area in which they operate. The National Research Council (1990) identified the shrimp fishery as the largest source of anthropogenic mortality to sea turtles. As a result of regulatory efforts by the NMFS $(1987,2003)$, the shrimp fishery, which operates almost exclusively south of Cape Hatteras, North Carolina, is now required to use TEDs in all places at all times. Two other regulated fisheries operating in the mid-Atlantic with documented incidental capture of sea turtles are the winter trawl fishery for summer flounder Paralichtys dentatus and the large-mesh gill net fishery for goosefish (monkfish) Lophius spp. (Epperly et al. 1995, 1996, NMFS 2001a). Since 1992, participants in the flounder winter trawl fishery have been required to use TEDs when fishing south of Cape Charles, Virginia $\left(37.083^{\circ} \mathrm{N}\right)(\mathrm{NMFS} 1992)$. This requirement is in effect for all times of the year for that fishery with the exception of January 15 to March 15, when the northern boundary for use of TEDs shifts south to Oregon Inlet, North Carolina $\left(35.775^{\circ} \mathrm{N}\right)$ (NMFS 1996). This and other bottom trawl fisheries also operate northward (Orphanides \& Magnusson 2007), and interactions with turtles occur north of the boundary where TEDs are not required (Murray 2006, 2007). Likewise, seasonal closures were enacted in the southern range of the monkfish gillnet fishery to reduce incidental capture of sea turtles (NMFS 2002), but do not include waters north of Virginia where this and other gillnet fisheries also occur (Palka \& Rossman 2001, Belden et al. 2006, New England Fishery Management Council 2007).

The NMFS is considering additional regulations to reduce the unintended bycatch of sea turtles in trawl and other fisheries along the Atlantic coast of the USA and in the Gulf of Mexico, including moving the northern boundary for TED regulations farther north and requiring TEDs in other fisheries (NMFS 2007). Our analysis of SST data could help predict marine cheloniid presence that may, in turn, provide guidance for mitigating sea turtle-fishery interactions.

It has been suggested that while autumn/winter movements out of an area appear to be initiated by SST decreases, spring/summer movements may be related to food resources (Bentivegna 2002). This implies that, although some minimal water temperature must be reached for turtles to avoid cold stunning 

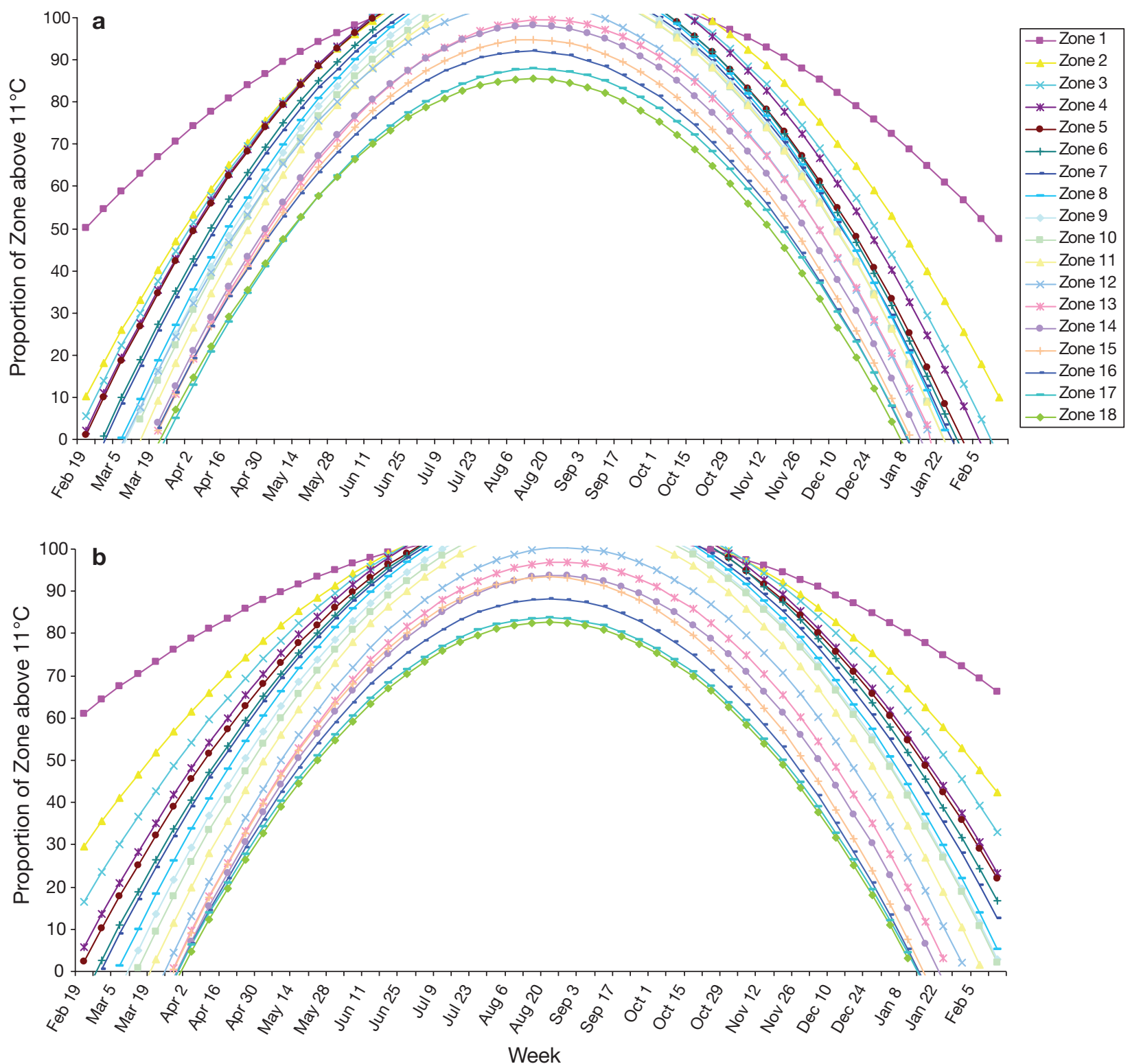

Fig. 2. Predicted proportion of (a) nearshore and (b) offshore zones $\geq 11^{\circ} \mathrm{C}$, by week, from 1993 to 2002 . Zones are defined in Fig. 1. Variability around these point estimates is not displayed. Note that the thermal minimum occurs in February and thus our year begins in February

in the autumn and winter, they may be tracking food resources as the water warms in the spring. If true, turtles may be present when a relatively small proportion of the area has reached a minimal temperature and food resources are present and, conversely, may not be present when food is absent and waters are relatively warm.

Thus, in addition to waters that reach or exceed a given minimal temperature, the likelihood of a marine cheloniid turtle being present in a particular zone increases as the proportion of the zone reaching that minimal temperature increases. Therefore, managers not only have to decide upon a given minimal temperature, but also need to determine what proportion of the zone must be at or above that temperature, thereby constituting an unacceptable risk and indicating a need for fishery restrictions. Dates determining the likelihood of a turtle being present can vary, depending upon the water temperature and proportion of a zone meeting or exceeding that water temperature.

Of the examples we provided (Fig. 4), the most conservative approach was $25 \%$ of a zone at or above $11^{\circ} \mathrm{C}$, while the least conservative approach was $50 \%$ of a zone at or above $14^{\circ} \mathrm{C}$. Epperly et al. (1995) 

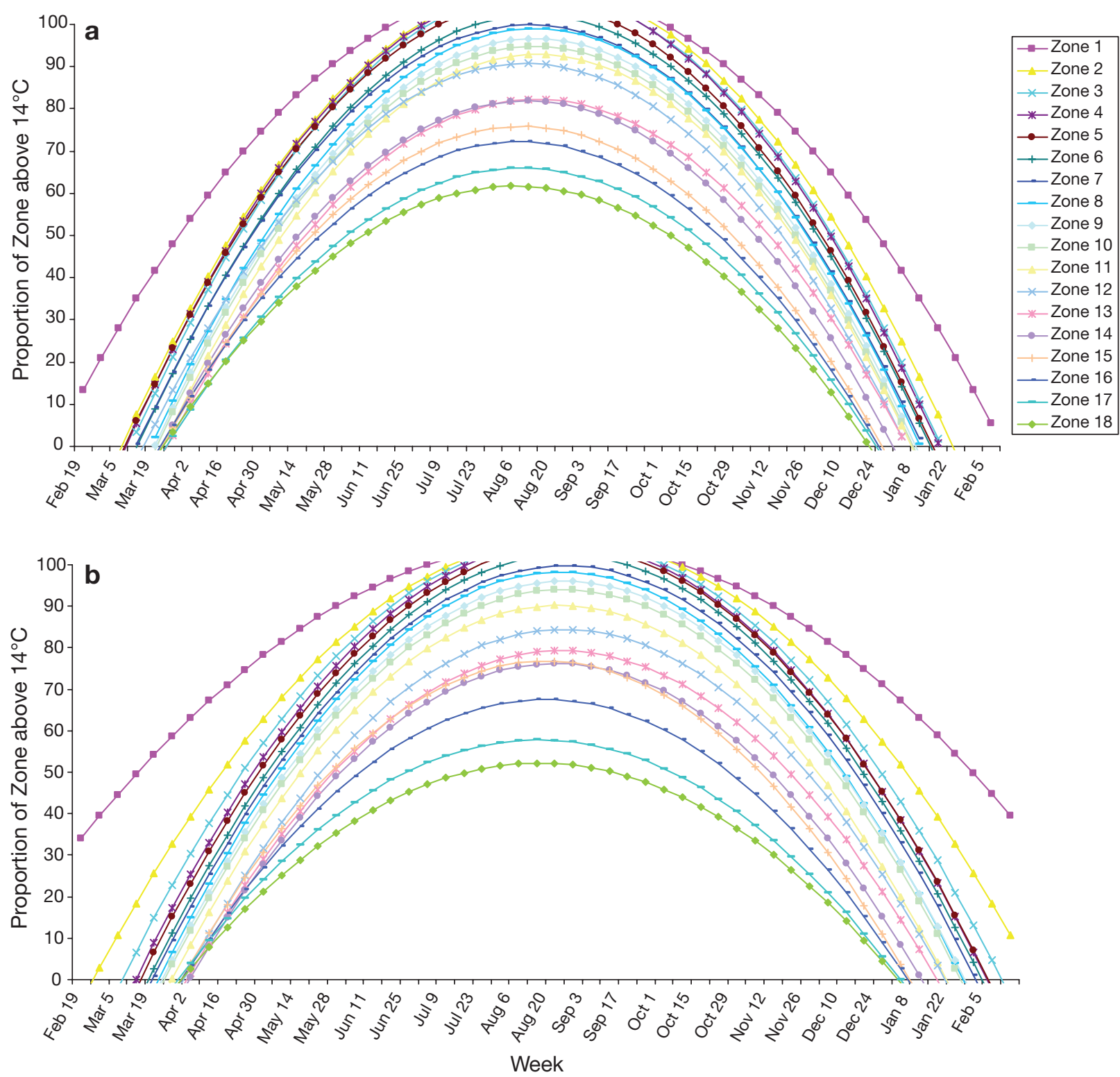

Fig. 3. Predicted proportion of (a) nearshore and (b) offshore zones $\geq 14^{\circ} \mathrm{C}$, by week, from 1993 to 2002 . The zones are defined in Fig. 1. Variability around these point estimates is not displayed. Note that the thermal minimum occurs in February and thus our year begins in February

Fig. 4. Caretta caretta, Lepidochelys kempii, Chelonia mydas, and Eretmochelys imbricata. Strandings $(\mathrm{n}=2487)$, sightings $(\mathrm{n}=$ $4845)$, and fishery bycatch $(\mathrm{n}=276)$ of loggerhead sea turtles north of $35^{\circ} \mathrm{N}$ in the United States Atlantic. Strandings are all species except leatherbacks and include only live, fresh dead, or moderately decomposed (not severely decomposed or dried carcasses) turtles found on the beaches; cold stuns and incidental captures are not included. Strandings data are from the period 1998 to 2004 (modified from Richards \& Belskis 2007). Sightings are from aerial and shipboard survey data contained in the Sea Turtle Atlantic Strategy GIS database (NMFS 2001b). North East Fishery Observer Program (NEFOP) fishery bycatch data are from the NMFS Northeast Fisheries Science Center and from Epperly et al. (1995) and show nearshore and offshore interactions. The SST analysis results for nearshore and offshore strata are depicted with 4 examples for each stratum: $\geq 25 \%$ of the area of a zone predicted to be $\geq 11^{\circ} \mathrm{C}$ in the nearshore and offshore strata $\left(\mathrm{N} .11^{\circ} 25 \%, 0.11^{\circ} 25 \%\right.$, respectively); $\geq 50 \%$ of the area of the zone predicted to be $\geq 11^{\circ} \mathrm{C}$ in the nearshore and offshore strata (N.11 $50 \%, 0.11^{\circ} 50 \%$, respectively); $\geq 25 \%$ of the area of a zone predicted to be $\geq 14^{\circ} \mathrm{C}$ in the nearshore and offshore strata (N.14 $25 \%$, O. $14^{\circ} 25 \%$, respectively); $\geq 50 \%$ of the area of a zone predicted to be $\geq 14^{\circ} \mathrm{C}$ in the nearshore and offshore strata (N.14 $50 \%, \mathrm{O} .14^{\circ} 50 \%$, respectively) 
Table 1. R-squared values of sea surface temperature polynomial curves for Zones 1 to 18, nearshore and offshore strata, from 1993 to 2002, for threshold temperatures of 11 and $14^{\circ} \mathrm{C}$. Zones and strata are defined in Fig. 1

\begin{tabular}{|lcccc|}
\hline Zone & $\begin{array}{c}\text { Nearshore } \\
11^{\circ} \mathrm{C}\end{array}$ & $\begin{array}{c}\text { Offshore } \\
14^{\circ} \mathrm{C}\end{array}$ & $\begin{array}{c}\text { Nearshore } \\
11^{\circ} \mathrm{C}\end{array}$ & $\begin{array}{c}\text { Offshore } \\
14^{\circ} \mathrm{C}\end{array}$ \\
\hline 1 & 0.42 & 0.26 & 0.61 & 0.41 \\
2 & 0.57 & 0.45 & 0.70 & 0.60 \\
3 & 0.64 & 0.54 & 0.73 & 0.69 \\
4 & 0.70 & 0.62 & 0.75 & 0.73 \\
5 & 0.75 & 0.61 & 0.76 & 0.72 \\
6 & 0.75 & 0.67 & 0.73 & 0.72 \\
7 & 0.76 & 0.67 & 0.74 & 0.73 \\
8 & 0.74 & 0.71 & 0.71 & 0.72 \\
9 & 0.76 & 0.73 & 0.71 & 0.71 \\
10 & 0.76 & 0.74 & 0.71 & 0.69 \\
11 & 0.73 & 0.79 & 0.66 & 0.70 \\
12 & 0.80 & 0.79 & 0.71 & 0.67 \\
13 & 0.79 & 0.76 & 0.67 & 0.64 \\
14 & 0.75 & 0.70 & 0.64 & 0.58 \\
15 & 0.71 & 0.70 & 0.56 & 0.57 \\
16 & 0.68 & 0.67 & 0.52 & 0.53 \\
17 & 0.65 & 0.64 & 0.46 & 0.47 \\
18 & 0.65 & 0.63 & 0.45 & 0.43 \\
\hline
\end{tabular}

reported turtles in Zone 1 during February, a time when we would predict as little as $10 \%$ of the area to be $>14^{\circ} \mathrm{C}$ (Fig. 3). This supports the position that only a relatively small proportion of a zone must exceed $14^{\circ} \mathrm{C}$ for turtles to be present in the southern part of our study area. In view of these findings, it is not unreasonable to assume that turtles begin migrating to zones farther north when relatively small proportions of the zone warm to this specific threshold temperature.

We compared these minimum temperature examples (Fig. 4) with what is known about sea turtle distributions in nearshore and offshore waters north of $35^{\circ} \mathrm{N}$, using strandings data (Richards \& Belskis 2007), observed captures (NMFS Northeast Fisheries Science Center unpubl. data and data from Epperly et al. 1995), and sightings data (NMFS Sea Turtle Atlantic Strategy GIS unpubl. database, NMFS 2001b). Strandings represent the spatio-temporal distribution of turtles in the nearshore waters off the northeast coast. Strandings are expected to lag behind the turtles' arrival at a nearshore area by several days to a couple weeks (Hart et al. 2006), and are expected to continue with a similar lag after turtles emigrate from a nearshore area, as

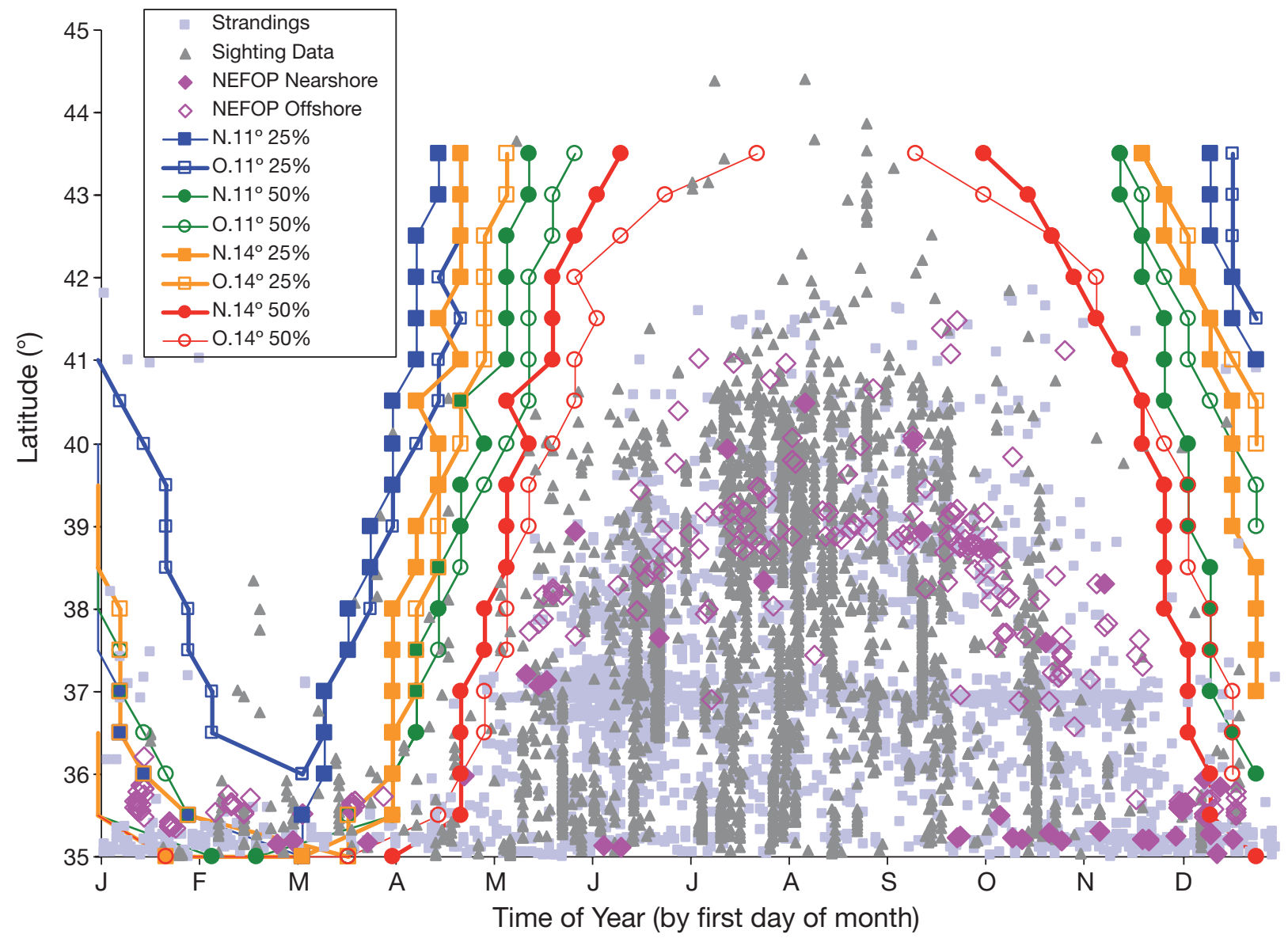


weakened individuals left behind die and as old carcasses are discovered. Observed captures mostly represent captures in offshore waters, as that was where the effort of the sampled fisheries was directed. Sightings from shipboard and aerial platforms were distributed in both nearshore and offshore waters. The spatio-temporal distribution of stranded turtles between Cape Hatteras, North Carolina, and Cape Cod, Massachusetts ( $n=2487$ ), correlates well with the above-mentioned minimum temperature examples for nearshore waters (Fig. 4; Richards \& Belskis 2007). The observer data $(\mathrm{n}=276)$ are comparable to the strandings data in their spatial distribution, but are slightly more restricted temporally, which could be a function of smaller sample size. The more numerous sightings ( $\mathrm{n}=4845$ ) show a greater distribution temporally and geographically than either the strandings or observed captures. In the southern zones, the data indicate that relatively few turtles occur in nearshore or offshore waters when $<25 \%$ of the area is $<11^{\circ} \mathrm{C}$, and in the northern zones relatively few occur in nearshore or offshore waters when $<50 \%$ of the area is $<14^{\circ} \mathrm{C}$.

This finding, along with few documented cheloniids north of $42^{\circ} \mathrm{N}$ (Shoop \& Kenney 1992) despite the fact that temperatures are warm enough during the summer to harbor cheloniid turtles (Fig. 4), led us to conclude that SST alone does not control the distribution of cheloniid sea turtles. Gardner et al. (2008, this Theme Section) determined that the relationship between the number of loggerheads captured in the North Atlantic pelagic longline fishery and temperature was not linear, but varied by region. In fact, the number of loggerheads captured off the northeast USA declined when water temperatures exceeded $21^{\circ} \mathrm{C}$ (Gardner et al. 2008). Thus, even though SST data can indicate the possible presence of cheloniid turtles in zones south of Cape Cod, their absence at northern latitudes at similar SSTs suggests the possible temporal unavailability of food resources or strong thermoclines restricting their bottom foraging abilities. These results indicate that: (1) use of minimum SST to manage interactions would be a conservative approach and (2) the choice of a minimum temperature or percent at or above that minimum temperature may be area specific and, if so, can be determined only with additional information on sea turtle distributions in the area of concern.

Although research has shown that temperature affects metabolic function and behavior and it is not unreasonable to expect a minimum water temperature for marine cheloniid turtles, their presence is also influenced by thermal fronts and ocean currents (Luschi et al. 2003), as well as food resources (Bentivegna 2002). In addition, because certain species of sea turtles (e.g. loggerheads) can regulate their body temperature to a certain extent via their large size, metabolism, or behavior (such as basking) (Spotila et al. 1997), they may be able to tolerate cooler water temperatures than other species of sea turtles, such as greens or Kemp's ridleys, which are much smaller off the northeast USA than loggerheads. Therefore, research is needed to identify the prevalence of migrating sea turtles in different water temperatures and to relate their presence not only to SSTs, but to other environmental parameters as well as the physiological, anatomical, and behavioral characteristics of the turtles.

Regardless, this analysis does provide a framework for conservatively predicting marine cheloniid turtle presence and, thus, could provide a means of regulating fisheries that seasonally interact with sea turtles. With the exception of Zone 1 ( 35 to $35.5^{\circ} \mathrm{N}$ ), where the frequent intrusion of Gulf Stream eddies in winter creates temperatures that are hospitable to turtles at all times (Epperly et al. 1995), surface water temperatures increase in a predictable movement up the Atlantic coast of the USA. Where turtles and fisheries are known to interact, managers also may consider the use of real-time monitoring of SST, onboard observers, and/or aerial surveys for turtles as temperatures begin to increase in the spring and decline in the autumn to reduce the likelihood of interactions.

Acknowledgements. The authors are grateful to Jon Hare and Charles Krouse for assisting with SST images; Larisa Avens, April Goodman, and Erica Nichols for helping to preview the hundreds of SST images; and Lisa Belskis for providing COLREG lines in a GIS overlay for us to identify the landward extent of the nearshore area in the vicinity of inlets and channels and for providing the strandings figure overlaid with the SST data. We also thank the STSSN coordinators and volunteers from North Carolina, Virginia, Maryland, Delaware, New Jersey, New York, Connecticut, Rhode Island, Massachusetts, New Hampshire, and Maine for collecting the strandings data, and the NOAA Fisheries Northeast Fisheries Science Center for providing their NEFOP data. The sightings data were compiled from a number of sources and are archived in the NOAA Fisheries Sea Turtle Atlantic Strategy GIS; those data were provided by Tanya Dobrzynski. Heather Haas provided the graphic for Fig. 4. Finally, this manuscript was improved greatly by comments from Dean Ahrenholz, Erik Davenport, Heather Haas, and anonymous reviewers. The NMFS does not approve, recommend, or endorse any proprietary product or material mentioned in this article.

\section{LITERATURE CITED}

Allen LK (2000) Protected species and New England fisheries: an overview of the problem and conservation strategies. Northeastern Naturalist 7:411-418

Belden DL, Orphanides CD, Rossman MC, Palka DL (2006) Estimates of cetacean and seal bycatch in the 2004 northeast sink gillnet and mid-Atlantic coastal gillnet fisheries. Ref. Doc. 06-13, US Dept. of Commerce, Northeast Fisheries Science Center, Woods Hole, MA. Available at: www.nefsc.noaa.gov/nefsc/publications/crd/crd0613/ 
Bentivegna F (2002) Intra-Mediterranean migrations of loggerhead sea turtles (Caretta caretta) monitored by satellite telemetry. Mar Biol 141:795-800

Birse RF, Davenport J (1987) A study of gut function in young loggerhead sea turtles, Caretta caretta L. at various temperatures. Herpetol J 1:170-175

Bleakney JS (1965) Reports of marine turtles from New England and eastern Canada. Can Field Nat 79:120-128

Braun-McNeill J, Epperly SP (2002) Spatial and temporal distribution of sea turtles in the western North Atlantic and the U.S. Gulf of Mexico from Marine Recreational Fisheries Statistics Survey (MRFSS). Mar Fish Rev 64:51-56

Carr A, Ogren L, McVea C (1980) Apparent hibernation by the Atlantic loggerhead turtle Caretta caretta off Cape Canaveral, Florida. Biol Conserv 19:7-14

$>$ Coles WC, Musick JA (2000) Satellite sea surface temperature analysis and correlation with sea turtle distribution of North Carolina. Copeia 2000:551-554

Davenport J, de Verteuil N, Magill SH (1997) The effects of current velocity and temperature upon swimming in juvenile green turtles Chelonia mydas L. Herpetol J 7:143-147

Epperly SP (2003) Fisheries-related mortality and turtle excluder devices (TEDs). In: Lutz P, Musick JA, Wyneken J (eds) The biology of sea turtles. CRC Press, Boca Raton, FL, p 339-353

Epperly SP, Braun J, Chester AJ, Cross FA, Merriner JV, Tester PA (1995) Winter distribution of sea turtles in the vicinity of Cape Hatteras and their interactions with the summer flounder trawl fishery. Bull Mar Sci 56:547-568

Epperly SP, Braun J, Chester AJ, Cross FA, Merriner JV, Tester PA, Churchill JH (1996) Beach strandings as an indicator of at-sea mortality of sea turtles. Bull Mar Sci 59:289-297

Epperly SP, Braun-McNeill J, Richards PM (2007) Trends in catch rates of sea turtles in North Carolina, USA. Endang Species Res 3:283-293

Gardner B, Sullivan PJ, Epperly S, Morreale SJ (2008) Hierarchical modeling of bycatch rates of sea turtles in the western North Atlantic. Endang Species Res 5:279-289

Goff GP, Lien J (1988) Atlantic leatherback turtles, Dermochelys coriacea, in cold water off Newfoundland and Labrador. Can Field Nat 102:1-5

Haas HL, LaCasella E, LeRoux RA, Milliken H, Hayward B (2008) Characteristics of sea turtles incidentally captured in the U.S. Atlantic sea scallop dredge fishery. Fish Res 93:289-293

Hart KM, Moorside P, Crowder LB (2006) Interpreting the spatio-temporal patterns of sea turtle strandings: going with the flow. Biol Conserv 129:283-290

Hawkes LA, Broderick AC, Coyne MS, Godfrey MH, Godley BJ (2007) Only some like it hot - quantifying the environmental niche of the loggerhead sea turtle. Divers Distrib 13:447-457

> Hochscheid S, Bentivegna F, Bradai MN, Hays G (2007) Overwintering behavior in sea turtles: dormancy is optional. Mar Ecol Prog Ser 340:287-298

> James MC, Mrosovsky N (2004) Body temperatures of leatherback turtles (Dermochelys coriacea) in temperate waters off Nova Scotia, Canada. Can J Zool 82:1302-1306

Keinath JA (1993) Movement and behavior of wild and headstarted sea turtles. PhD thesis, College of William \& Mary, Gloucester Point, VA

> Lazell JD Jr (1980) New England waters: critical habitat for marine turtles. Copeia 1980:290-295

Ledwell W (2007) Live loggerhead observed in Newfoundland, Canada in late autumn. Mar Turtle Newsl 115:17

Luschi P, Hays GC, Papi F (2003) A review of long-distance movements by marine turtles, and the possible role of ocean currents. Oikos 103:293-302

Lutz P, Dunbar-Cooper A (1984) Final report to the National Marine Fisheries Service for FSE 81-125-60. National Marine Fisheries Service, Miami, FL. Available at: www. sefsc.noaa.gov/seaturtlecontractreports.jsp

Lutz P, Bergey A, Bergey M (1989) Effects of temperature on gas exchange and acid-base balance in the sea turtle Caretta caretta at rest and during routine activity. J Exp Biol 144:155-169

Milton SL, Lutz PL (2003) Physiological and genetic responses to environmental stress. In: Lutz PL, Musick JA, Wyneken J (eds) The biology of sea turtles, Vol II. CRC Press, Boca Raton, FL, p 163-197

Moon DY, MacKenzie DS, Owens DA (1997) Simulated hibernation of sea turtles in the laboratory. I. Feeding, breathing frequency, blood $\mathrm{pH}$, and blood gases. J Exp Zool 278:372-380

Morreale SJ, Standora EA (1998) Early life stage ecology of sea turtles in northeastern U.S. waters. NOAA Tech Memo 413:1-49

Morreale SJ, Standora EA (2005) Western North Atlantic waters: crucial developmental habitat for Kemp's ridley and loggerhead sea turtles. Chelonian Conserv Biol 4: 872-882

Murray KT (2006) Estimated average annual bycatch of loggerhead sea turtles (Caretta caretta) in U.S. mid-Atlantic bottom otter trawl gear, 1996-2004. Ref. Doc. 06-19, US Dept. of Commerce, Northeast Fisheries Science Center, Woods Hole, MA. Available at: www.nefsc.noaa.gov/ nefsc/publications/crd/crd0619/

Murray KT (2007) Estimated bycatch of loggerhead sea turtles (Caretta caretta) in U.S. mid-Atlantic scallop trawl gear, 2004-2005, and in sea scallop dredge gear, 2005. Ref Doc 07-04, US Dept. of Commerce, Northeast Fisheries Science Center, Woods Hole, MA. Available at: www. nefsc.noaa.gov/nefsc/publications/crd/crd0704

Musick JA, Limpus CJ (1997) Habitat utilization and migration in juvenile sea turtles. In: Lutz PL, Musick JA (eds) The biology of sea turtles. CRC Press, Boca Raton, FL, p 137-163

National Research Council (1990) Decline of the sea turtles: causes and prevention. National Academy Press, Washington, DC

New England Fishery Management Council (2007) Monkfish fishery management plan. Framework Adjustment 4, incorporating stock assessment and fishery evaluation (SAFE). Report for the 2005 fishing year and the environmental assessment and regulatory impact review. Available at: www.nero.noaa.gov/nero/regs/frdoc/07/ 07MonkfishFW4EA.pdf (last accessed: 29 October 2008)

NMFS (National Marine Fisheries Service) (1987) Sea Turtle Conservation; Shrimp Trawling Requirements. Federal Register 52, No. 124 (June 29, 1987) 24244-24262

NMFS (National Marine Fisheries Service) (1992) Sea Turtle Conservation; Restrictions Applicable to Fishery Activities. Federal Register 57, No. 219 (November 12, 1992) 53603-53605

NMFS (National Marine Fisheries Service) (1996) Sea Turtle Conservation; Restrictions Applicable to Fishery Activities; Summer Flounder Fishery-Sea Turtle Protection Area. Federal Register 61, No. 16 (January 24, 1996) $1846-1848$

NMFS (National Marine Fisheries Service) (2001a) Endangered Species Act Section 7 Consultation. Biological opinion. Authorization of fisheries under Monkfish Fishery Management Plan [Consultation No. F/NEW/2001/ 
00546]. National Marine Fisheries Service Northeast Regional Office, Gloucester, MA

NMFS (National Marine Fisheries Service) (2001b) Sea Turtle Conservation; Restrictions Applicable to Fishery Activities; Federal Register 66, No. 147 (July 31, 2001) 39474-39475

NMFS (National Marine Fisheries Service) (2002) Sea turtle conservation; Activities related to fishing. Federal Register 67, No. 232 (December 3, 2002) 71895-71900

NMFS (National Marine Fisheries Service) (2003) Endangered and Threatened Wildlife; Sea Turtle Conservation Requirements. Federal Register 68, No, 35 (February 21, 2003) 8456-8471

NMFS (National Marine Fisheries Service) (2005) Endangered Species Act Section 7 Consultation. Biological opinion. The continued authorization of reef fish fishing under the Gulf of Mexico (GOM) Reef Fish Management Plan (RFMP) and Proposed Amendment 23, February 2005. National Marine Fisheries Service Southeast Regional Office, St. Petersburg, FL

NMFS (National Marine Fisheries Service) (2007) Endangered and Threatened Wildlife; Sea Turtle Conservation Requirements. Federal Register 72, No. 31 (February 15, 2007) 7382-7384

NMFS SEFSC (National Marine Fisheries Service Southeast Fisheries Science Center) (2001) Stock assessments of loggerhead and leatherback sea turtles and an assessment of the impact of the pelagic longline fishery on the loggerhead and leatherback sea turtles of the western North Atlantic. NOAA Tech Mem 455:1-343. Available at: www.sefsc. noaa.gov/seaturtletechmemos.jsp

NCMFC (North Carolina Marine Fisheries Commission) Sea Turtle Advisory Committee (2006) Sea turtle interactions with North Carolina fisheries, review and recommendations. North Carolina Marine Fisheries Commission, Morehead City, NC

Orphanides CD, Magnusson GM (2007) Characterization of the northeast and mid-Atlantic bottom and mid-water trawl fisheries based on vessel trip report (VTR) data. Ref. Doc. 07-15, US Dept. of Commerce, Northeast Fisheries

Editorial responsibility: Rebecca Lewison, San Diego, California, USA
Science Center, Woods Hole, MA. Available at: www. nefsc.noaa.gov/nefsc/publications/crd/crd0715/

Palka DL, Rossman MC (2001) Bycatch estimates of coastal bottlenose dolphin (Tursiops truncatus) in U.S. midAtlantic gillnet fisheries for 1996 to 2000. Ref. Doc. 01-15, US Dept. of Commerce, Northeast Fisheries Science Center, Woods Hole, MA. Available at: www.nefsc.noaa.gov/ nefsc/publications/crd/crd0115/0115.htm

Richards PM, Belskis LC (2007) A report to the Atlantic Sea Turtle Strategy Steering Committee: latitudinal distribution of sea turtles reported to the Sea Turtle Stranding and Salvage Network on the northern east coast of the United States using preliminary information from 1998-2004. National Marine Fisheries Service, Southeast Fisheries Science Center, Miami, FL. Available at: www.sefsc. noaa.gov/seaturtleunpublishedreports.jsp

Schwartz FJ (1978) Behavioral and tolerance responses to cold water temperatures by three species of sea turtles (Reptilia, Cheloniidae) in North Carolina. Fla Mar Res Publ 13:16-18

Shoop CR, Kenney RD (1992) Seasonal distributions and abundances of loggerhead and leatherback sea turtles in waters of the northeastern United States. Herpetological Monogr 6:43-67

Spotila JR, O'Connor MP, Paladino FV (1997) Thermal biology. In: Lutz PL, Musick J (eds) The biology of sea turtles. CRC Press, Boca Raton, FL, p 297-314

Standora EA, Morreale SJ, Thompson RD, Burke VJ (1990) Telemetric monitoring of diving behavior and movements of juvenile Kemp's ridleys. In: Richardson TH, Richardson JI, Donnelly M (compilers) Proceedings of the 10th annual workshop on sea turtle biology and conservation. NOAA Tech Mem 278:1-133 (Available at: www.sefsc.noaa.gov/ seaturtletechmemos.jsp)

Witzell WN, Azarovitz T (1996) Relative abundance and thermal and geographic distribution of sea turtles off the U.S. Atlantic coast based on aerial surveys (1963-1969). NOAA Tech Mem 381:1-10 (Available at: www.sefsc.noaa.gov/ seaturtletechmemos.jsp)

Submitted: March 5, 2008; Accepted: September 16, 2008 Proofs received from author(s): November 3, 2008 